\title{
Design and Performance Study of a Hot Water Driven 5 TR Capacity Absorption Cooling System
}

\author{
Anil Sharma ${ }^{1}$, Bimal Kumar Mishra ${ }^{2}$, Abhinav Dinesh $^{3}$ and Ashok Misra ${ }^{4}$ \\ ${ }^{1}$ Department of Production Engineering, Birla Institute of Technology,Deoghar, \\ India \\ ${ }^{2}$ Department of Mathematics, Birla Institute of Technology, Ranchi, India \\ ${ }^{3}$ Department of Electronics \& Communication Engineering, Birla Institute of \\ Technology, Jaipur, India \\ ${ }^{4}$ Department of Mechanical Engineering, RTC Institute of Technology, Ranchi, \\ India
}

\begin{abstract}
Use of high grade electrical energy, generated from fossil fuels, for cooling has increased environmental concerns like global warming and ozone layer depletion. Hence, there is a need to reduce dependence on them and explore potential environmental friendly options. In this aspect, vapor absorption system has scope of utilizing low grade energy source i.e. hot water from solar panel, to generate cooling effect and are environment friendly as no chloro-floro-carbons are used. The most usual combination of absorber refrigerant pair in such system is lithium bromide water $\left(\mathrm{LiBr}-\mathrm{H}_{2} \mathrm{O}\right)$, where water vapor is the refrigerant. In present work, a hot water driven, single stage, absorption cooling system, using a lithium bromide water solution, is analyzed for determining the effect of various parameters on coefficient of performance (COP). Four basic stages in the absorption cycle are generation, condensation, evaporation and absorption with ideally no moving part. A configuration of theses four stages, having 5 TR cooling capacity is determined and examined for the variation in COP corresponds to the change in pressure and concentration. The pressure parameter is varied in condenser and evaporator, resulting graph shows that the increment in pressure of evaporator increases the COP whereas increment of pressure in condenser decreases the COP. At lower inlet concentration of LiBr solution to the absorber gives increment in COP.
\end{abstract}

Keywords: Absorption cycle, low grade energy, system configuration, coefficient of performance

\section{Introduction}

Absorption and vapor compression technologies for space cooling are based on the principle of condensation and evaporation of a refrigerant. In compression systems the most common source of energy for the work required to compress the vapor is electricity, whereas in absorption systems it is heat, fed directly to the generator. Such thermally driven absorption refrigeration systems provides cooling effect by using heat as source energy, which can be obtained from solar energy, waste-heat sources and other forms of low grade heat.

Among various absorbent and refrigerant pair, $\mathrm{LiBr}-$ Water is most promising in chiller application due to high safety, high volatility ratio, high affinity, high stability and high latent heat. In the cycle, shown in Figure 1, water vapor evaporates and separates from aqueous $\mathrm{LiBr}$ solution in generator, and increases the concentration of $\mathrm{LiBr}$ in solution. For this process heat is supplied from external source. At the same pressure, the water vapors from generator are condensed in condenser and this condensed water is throttled to the 
evaporator, which is at lower pressure. Due to reduced pressure, the water change phase and evaporate by taking latent heat of vaporization in the evaporator at low temperature and generates the cooling effect.

\section{Nomenclature}

$\begin{array}{ll}\mathrm{h} & \text { specific enthalpy }(\mathrm{KJ} / \mathrm{kg}) \\ \mathrm{m} & \text { mass flow rate }(\mathrm{kg} / \mathrm{sec}) \\ \mathrm{P} & \text { pressure }(\mathrm{kPa}) \\ \mathrm{Q} & \text { Heat transfer rate }(\mathrm{kW}) \\ \mathrm{s} & \text { Specific Entropy }\left(\mathrm{kJ} / \mathrm{kg}^{\mathrm{O}} \mathrm{K}\right) \\ \mathrm{T} & \text { Temperature }\left({ }^{\mathrm{O}} \mathrm{K}\right) \\ \mathrm{X} & \text { LiBr mass fraction }(\%) \\ \mathrm{COP} & \text { Coefficient of Performance }\end{array}$

$\begin{array}{ll}\text { Subscript: } \\ i & \text { inlet } \\ e & \text { exit } \\ a & \text { absorber } \\ g & \text { generator } \\ e & \text { evaporator } \\ c & \text { condensor }\end{array}$

$1,2,3 \ldots$ represent state point in Figure 1

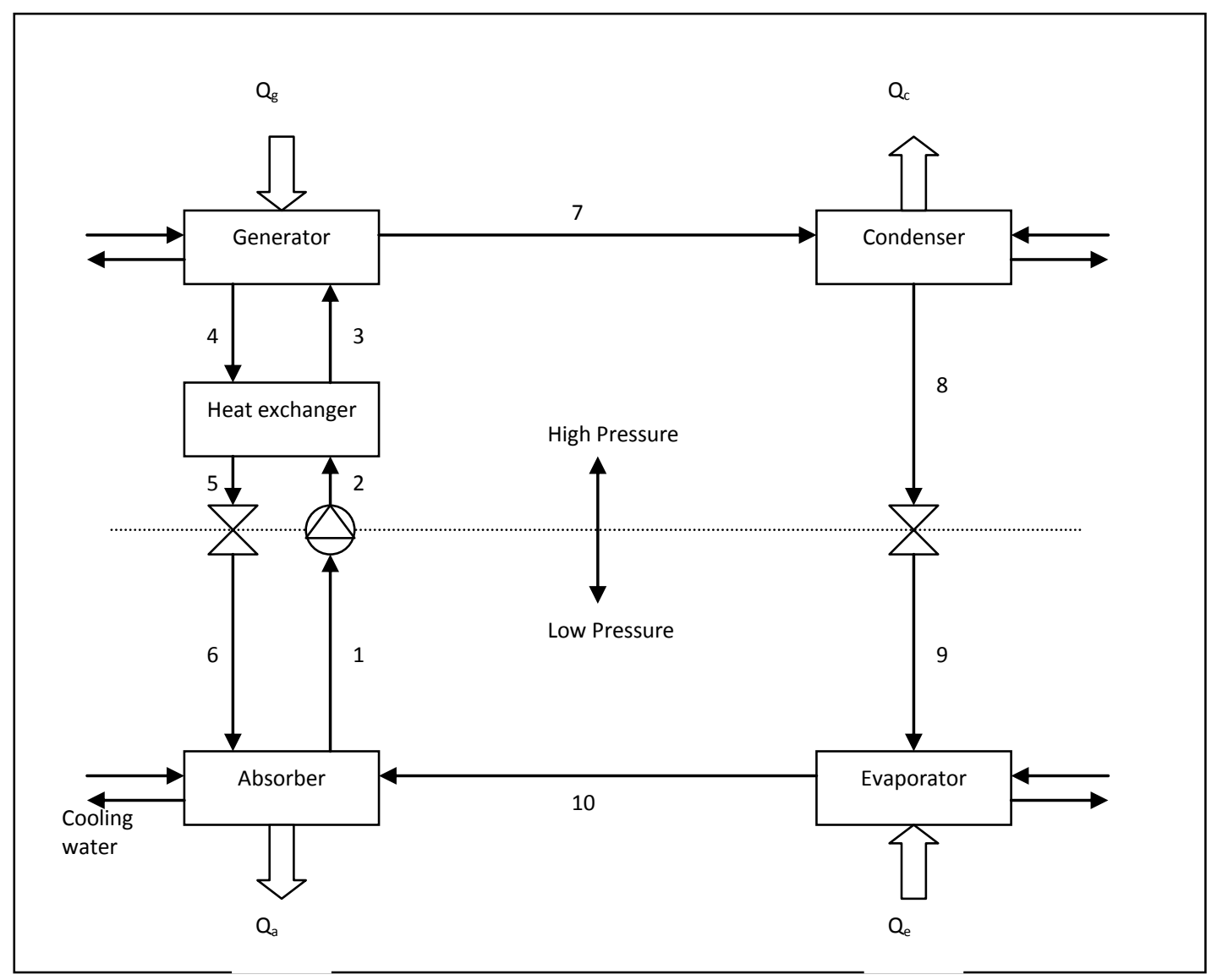

Figure 1. Schematic of a Single effect LiBr-Water Absorption System

At same pressure, the vapors from evaporator are absorbed by $\mathrm{LiBr}$-aqueous solution supplied form generator having higher concentration of $\mathrm{LiBr}$. The absorption of water vapor reduces the concentration of $\mathrm{LiBr}$ in aqueous solution; this solution is then passed to generator through pump at higher pressure. A solution heat exchanger is used between absorber and generator to increase the efficiency of system.

In this paper, a 5 TR $(17.585 \mathrm{~kW})$ capacity absorption system is simulated; to which heat is sourced for generator from hot i.e. $92^{0} \mathrm{C}$ at atmospheric pressure. This low grade energy can be obtained from solar panel, cooling of automobile engine, and other source of waste heat. Various components of the cycle are configured using empirical correlations and their 
specifications had been determined. To release the heat, cooling water is circulated in absorber and condenser at ambient temperature.

\section{Heat and Mass Transfer Calculations}

\subsection{Mass Flow Rate Calculations}

Mass flow rate in evaporator $\left(\mathrm{m}_{9}\right)=$ Load $/$ (Change in enthalpy)

Mass flow rate for weak and strong solution

$\mathrm{m}_{4} \times \mathrm{Xia}=\mathrm{m}_{3} \times \mathrm{Xig}$

Also, $\mathrm{m}_{3}=\mathrm{m}_{4}+\mathrm{m}_{7}$

And $\mathrm{m}_{1}=\mathrm{m}_{2}=\mathrm{m}_{3} ; \quad \mathrm{m}_{4}=\mathrm{m}_{5}=\mathrm{m}_{6} ; \quad$ and $\quad \mathrm{m}_{7}=\mathrm{m}_{8}=\mathrm{m}_{9}=\mathrm{m}_{10}$

\subsection{Heat Transfer Rate}

Heat transfer rate in evaporator is taken as 5 TR (Load), base on this selected parameter heat transfer rate at other components are calculated as follows.

\subsubsection{At Condenser}

$\mathrm{Qc}=\mathrm{m}_{7}\left(\mathrm{~h}_{7}-\mathrm{h}_{8}\right)$

$\mathrm{h}_{7}=$ Enthalpy of super heated steam at saturation temperature of solution in generator and Condenser pressure

$\mathrm{h}_{8}=$ Enthalpy of water (saturated liquid) at condenser pressure and saturated temperature.

\subsubsection{At Generator}

$\mathrm{Qg}=\mathrm{m}_{4} \mathrm{~h}_{4}+\mathrm{m}_{7} \mathrm{~h}_{7}-\mathrm{m}_{3} \mathrm{~h}_{3}$

$\mathrm{h}_{4}=$ Enthalpy of solution at exit of generator temperature and $\mathrm{X}_{\mathrm{ia}}$ Concentration

$\mathrm{h}_{3}=$ Enthalpy of solution at inlet of generator temperature and $\mathrm{X}_{\mathrm{ig}}$ concentration.

\subsubsection{At Absorber}

$\mathrm{Qa}=\mathrm{m} 6 \mathrm{~h} 6+\mathrm{m}_{10} \mathrm{~h}_{10}-\mathrm{m}_{1} \mathrm{~h}_{1}$

$\mathrm{h}_{6}=$ Enthalpy of solution at inlet of absorber temperature and $\mathrm{X}_{\mathrm{ia}}$ concentration

$\mathrm{h}_{10}=$ Enthalpy of saturated water vapor at evaporator pressure and its saturation temperature.

$\mathrm{h}_{1}=$ Enthalpy of solution at exit of absorber temperature and $\mathrm{X}_{\mathrm{ea}}$ concentration.

\subsection{Coefficient of Performance (COP)}

COP $($ ideal $)=$ Heat taken out in Evaporator $/$ Heat supplied in generator

$$
=\mathrm{Qe} / \mathrm{Qg}
$$


In the above ideal COP, work by the pump, pressure drops and other losses are not included.

Lower value of COP for absorption system compare to compression technology is because of using low grade energy rather than highly concentrated electric energy.

\section{Configuration of a 5 TR System}

\subsection{Selection of Operating Parameters}

After considering the optimum values in respect to ambient temperature, water properties and chilling requirements, following operating parameters are selected for various components of the cycle as shown in Table 1.

Table 1. Operating Parameters for Cycle

\begin{tabular}{|l|l|}
\hline Pressure in generator and condenser & $7 \mathrm{kPa}$ \\
\hline Pressure in absorber and evaporator & $1 \mathrm{kPa}$ \\
\hline Saturation temperature in generator & $82.863^{0} \mathrm{C}$ \\
\hline Saturation temperature in condenser & $38.199^{0} \mathrm{C}$ \\
\hline Saturation temperature in evaporator & $6.315^{0} \mathrm{C}$ \\
\hline Solution Temperature in absorber & $36{ }^{0} \mathrm{C}$ \\
\hline Solution Concentration at 3 & $55 \%$ \\
\hline Solution Concentration at 5 & $60 \%$ \\
\hline Evaporator capacity & $5 \mathrm{TR}$ \\
\hline
\end{tabular}

\subsection{Configuration of Heat Exchangers}

Configuration for heat exchangers based on various empirical correlations is shown in Table 2. Standard dimensions of copper tubes had been selected from manufacturer's guide. Table: 2 reveal that the absorber is having maximum dimensions among other and the compactness of complete system depends on the size of absorber.

\section{Coefficient of Performance Analysis}

\subsection{Effect of Solution Concentration}

To check the solution concentration effectiveness, a constant difference of $5 \%$ between the absorber inlet $\mathrm{LiBr}$ percentage ratio $\left(\mathrm{X}_{\mathrm{ia}}\right)$ and absorber exit ratio $\left(\mathrm{X}_{\mathrm{ea}}\right)$ are considered.

Table 2. Specifications of Components

\begin{tabular}{|l|l|l|l|l|}
\hline & Absorber & Evaporator & Generator & Condenser \\
\hline $\begin{array}{l}\text { Inner diameter of } \\
\text { tube }\end{array}$ & 0.545 inch & 0.43 inch & 0.545 inch & 0.43 inch \\
\hline $\begin{array}{l}\text { Outer diameter of } \\
\text { tube }\end{array}$ & 0.625 inch & 0.5 inch & 0.625 inch & 0.5 inch \\
\hline Number of tubes & 38 & 18 & 16 & 8 \\
\hline Tube orientation & Vertical & Vertical & Horizontal & Horizontal \\
\hline Length of tubes & $1.2 \mathrm{~m}$ & $1.2 \mathrm{~m}$ & $\begin{array}{l}2.7 \mathrm{~m} \text { (with one } \\
\text { shell pass) }\end{array}$ & $\begin{array}{l}2.2 \mathrm{~m} \text { (with one } \\
\text { shell pass) }\end{array}$ \\
\hline $\begin{array}{l}\text { Overall heat transfer } \\
\text { coefficient }\left(\mathrm{W} / \mathrm{m}^{20} \mathrm{C}\right)\end{array}$ & 487.43 & 1507.07 & 719.35 & 1782.19 \\
\hline $\begin{array}{l}\text { Water inlet } \\
\text { temperature }\end{array}$ & $\begin{array}{l}28^{0} \mathrm{C} \\
\mathrm{Cooling}\end{array}$ & $\begin{array}{l}12^{0} \mathrm{C} \\
\mathrm{Chilled}\end{array}$ & $\begin{array}{l}92^{0} \mathrm{C} \\
\mathrm{Hot}\end{array}$ & $\begin{array}{l}28^{0} \mathrm{C} \\
\text { Cooling }\end{array}$ \\
\hline
\end{tabular}




\begin{tabular}{|l|l|l|l|l|}
\hline $\begin{array}{l}\text { Water exit } \\
\text { temperature }\end{array}$ & $\begin{array}{l}31^{\circ} \mathrm{C} \\
\text { Cooling }\end{array}$ & $\begin{array}{l}8^{0} \mathrm{C} \\
\text { Chilled }\end{array}$ & $\begin{array}{l}84^{0} \mathrm{C} \\
\text { Hot }\end{array}$ & $\begin{array}{l}34^{0} \mathrm{C} \\
\text { Cooling }\end{array}$ \\
\hline $\begin{array}{l}\text { Log mean } \\
\text { temperature } \\
\text { difference (LMTD) }\end{array}$ & 18 & 13.5 & 17 & 19.61 \\
\hline
\end{tabular}

The $\mathrm{x}$-axis in graph 1 represents the exit concentration of solution in absorber. The concentration of $\mathrm{LiBr}$ solution decrease while passing through the absorber due to absorption of water vapor. Enthalpy, which is a function of $\mathrm{LiBr}$ solution concentration and temperature at various state points as referred in figure 1 are determined using properties of solution from reference [2]. Following conditions are assumed:

1. Evaporator capacity $5 \mathrm{TR}$.

2. Solution heat exchanger exit temperature, $69.36^{\circ} \mathrm{C}$.

3. Generator solution exit temperature, $82.86^{\circ} \mathrm{C}$.

4. Absorber solution exit temperature, $55.86^{\circ} \mathrm{C}$.

5. Saturation temperature in condenser, $38.19^{\circ} \mathrm{C}$

6. Saturation temperature in evaporator, $6.315^{\circ} \mathrm{C}$.

7. Pressure in generator and condenser $7 \mathrm{kPa}$.

8. Pressure in absorber and evaporator $1 \mathrm{kPa}$.

\subsection{Effect of Evaporator Pressure on COP.}

To check this effect, the following conditions were assumed:

1. Evaporator capacity 5 TR.

2. Solution heat exchanger exit temperature, $69.36^{\circ} \mathrm{C}$.

3. Generator solution exit temperature, $82.86^{\circ} \mathrm{C}$.

4. Absorber solution exit temperature, $55.86^{\circ} \mathrm{C}$.

5. Saturation temperature in condenser $38.19^{\circ} \mathrm{C}$.

6. Pressure in condenser $7 \mathrm{kPa}$.

7. Absorber inlet $\mathrm{LiBr}$ concentration (\%) 60 .

8. Absorber exit $\mathrm{LiBr}$ concentration (\%) 55.

The graph: 2 show the variation in COP corresponds to different pressure in evaporator.

\subsection{Effect of Condenser Pressure on COP}

To check this effect, the following conditions were assumed:

1. Evaporator capacity 5 TR.

2. Solution heat exchanger exit temperature, $69.36^{\circ} \mathrm{C}$.

3. Generator solution exit temperature, $82.86^{\circ} \mathrm{C}$.

4. Absorber solution exit temperature, $55.86^{\circ} \mathrm{C}$.

5. Saturation temperature in evaporator, $6.315^{\circ} \mathrm{C}$.

6. Pressure in absorber and evaporator $1 \mathrm{kPa}$.

7. Absorber inlet $\mathrm{LiBr}$ concentration (\%) 60 .

8. Absorber exit $\mathrm{LiBr}$ concentration (\%) 55.

The graph: 3 show the variation in $\mathrm{COP}$ corresponds to different pressure in condenser. 

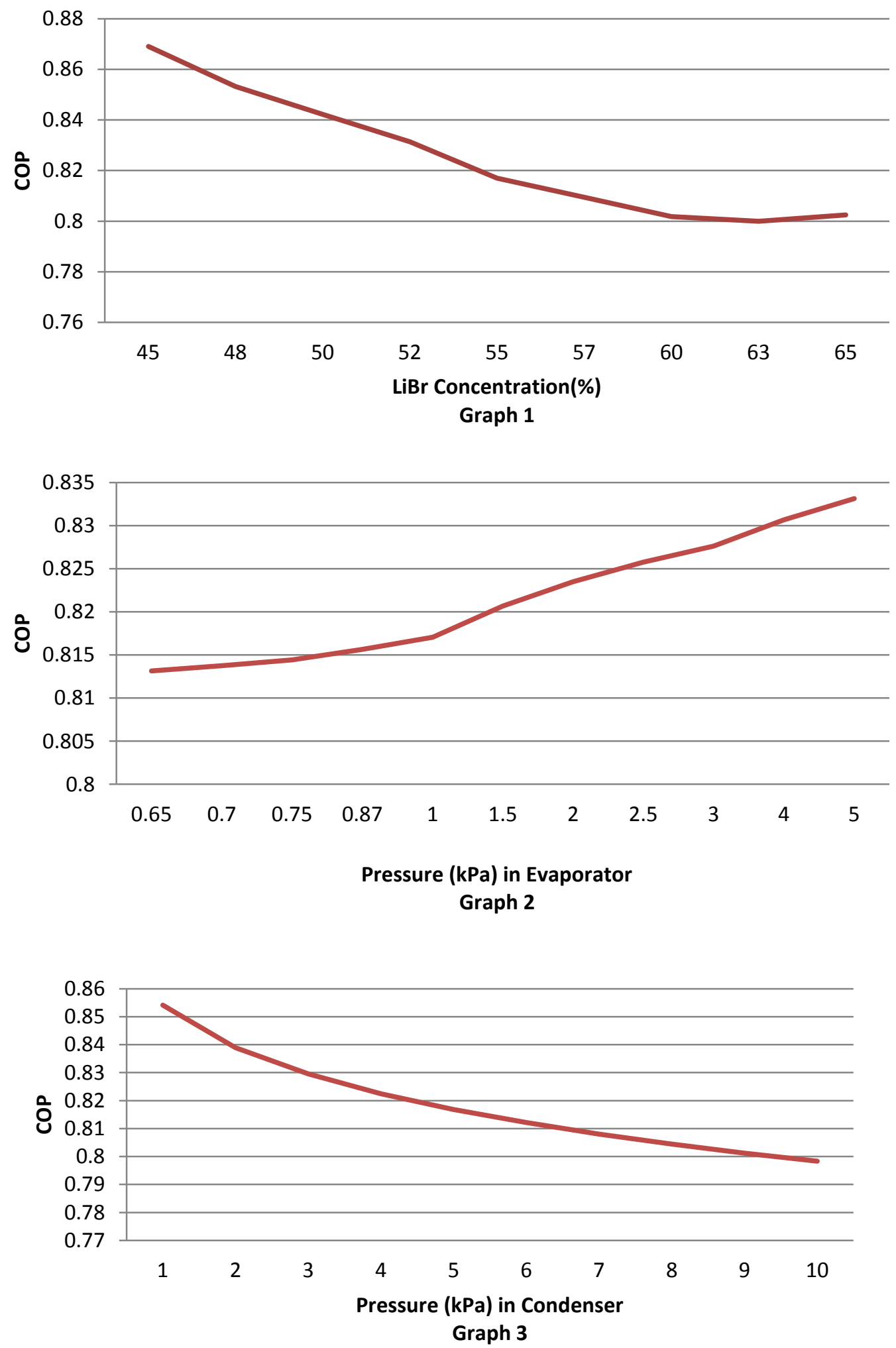

\section{Results and Discussion}

By using empirical correlations related with heat and mass transfer, specifications for various heat exchangers in the absorption cycle were determined in Table 2. Among all components, size of the absorber is maximum and affects the compactness of the overall system. The assumed temperature of cooling water availability depends on the ambient 
temperature, which can affect the overall dimensions of the system. Use of solution heat exchanger reduces the overall size of the system, and increases the efficiency. Generated graph 1 gives the COP variation with exit concentration of $\mathrm{LiBr}$ solution in absorber. The $\mathrm{COP}$ is more at the low exit concentration and reduces as the exit concentration increase. The graph is plot with constant difference of 5\% in concentration. The concentration reduces due to affinity of solution to absorb water vapors. Graph 2 shows that, increasing pressure in evaporator gives more COP, but this need to be considered with the required chilling water temperature, as at higher pressure the saturation temperature of water increases which again make the chilling unfeasible compare to ambient temperature. Therefore the atmospheric temperature is an important criterion for the selection of optimum pressures in the condenser as well as in the absorber. Graph 3 shows that, at low pressure in condenser the COP is more, but the saturation temperature of water also reduces, which make the low pressure in condenser unfeasible due to cooling water availability from the ambient temperature.

Hot water as a driving source for the system can be obtained from various renewable or waste heat sources, specifically from flat solar panel in desert area where ambient temperature reaches up to $50^{\circ} \mathrm{C}$ in summer and cooling requirement is at peak.

\section{Conclusion}

Such modeling of thermal systems presents many advantages; the most important are the elimination of the expense of building prototypes, the optimization of the system components, estimation of the amount of energy delivered from the system, and prediction of temperature variations of the system. In current paper, specification of 5 TR capacity absorption systems provides fundamental information about the product design and economic feasibility of the system being driven by hot water. The performance of the system is discussed in corresponds to parameters such as concentration, pressure and temperature, which helps in optimum selection of parameters.

The current calculations have used some assumptions which need further study i.e. no jacket heat loss. In the analysis of absorber, empirical correlation for outside heat transfer coefficient ignores the fact of simultaneous mass transfer. Other fields of investigation are creating and sustaining vacuum, throttling process and optimum size of pump.

\section{References}

[1] F. Asdrubali and S. Grignaffini, "Experimental evaluation of the performances of a $\mathrm{H}_{2} \mathrm{O}-\mathrm{LiBr}$ absorption refrigerator under different service conditions", International Journal of Refrigeration, vol. 28, (2005), pp. 489-497.

[2] ASHRAE Handbook of fundamentals, (1997).

[3] D. Bredow, P. Jain, A. Wohlfeil and F. Ziegler, "Heat and mass transfer characteristics of a horizontal tube absorber in a semi-commercial absorption chiller", International Journal of Refrigeration, vol. 31, (2008), pp. 1273-1281.

[4] J. Castro, A. Oliva, C. D. Segarra and C. Oliet, "Modeling of the heat exchangers of a small capacity, hot water driven, air-cooled $\mathrm{H} 2 \mathrm{O}-\mathrm{LiBr}$ absorption cooling machine", International Journal of Refrigeration, vol. 31, (2008), pp. 75-86.

[5] G. A. Florides, S. A. Kalogirou, S. A. Tassou and L. C. Wrobel, "Design and construction of a LiBr-water absorption machine", Energy Conversion and Management, vol. 44, (2003), pp. 2483-2508.

[6] O. Kaynakli and I. Horuz, "Comparison of parallel and counter flow coil absorber performance", International Communications in Heat and Mass Transfer, vol. 33, (2006), pp. 211-223.

[7] P. Kohlenbach and F. Ziegler, "A dynamic simulation model for transient absorption chiller performance", Part-I: The Model, Part-II: Numerical results and experimental verification, International Journal of Refrigeration, vol. 31, (2008), pp. 217-233.

[8] I. Kyung, K. E. Herold and Y. T. Kang, "Experimental verification of H2O/LiBr absorber bundle performance with smooth horizontal tubes", International Journal of Refrigeration, vol. 30, (2007), pp. 582-590.

[9] R. D. Misra, P. K. Sahoo, S. Sahoo and A. Gupta, "Thermo economic optimization of a single effect water/LiBr vapour absorption refrigeration system”, International Journal of Refrigeration, vol. 26, (2003), pp. 158-169. 
[10] V. D. Papaefthimiou, D. C. Karampinos and E. D. Rogdakis, "A detailed analysis of water-vapour absorption in $\mathrm{LiBr}-\mathrm{H} 2 \mathrm{O}$ solution on a cooled horizontal tube", Applied Thermal Engineering, vol. 26, (2006), pp. 2095-2102.

[11] V. Patnaik and H. Perez-Blanco, "A study of absorption enhancement by wavy film flows", International Journal of Heat and Fluid Flow, vol. 17, (1996), pp. 71-77.

[12] A. Sencan, K. A. Yakut and S. A. Kalogirou, "Exergy analysis of lithium bromide/water absorption systems", Renewable Energy, Elsevier, vol. 30, (2005), pp. 645-657.

[13] A. Sharma, B. K. Mishra, A. Dinesh and A. Misra, "Theoretical investigation and parametric study of a solar driven absorption refrigeration system", Renewable Energy Asia 2008 - An International Conference \& 4th SEE Forum Meeting, Center for Rural Development and Technology, Indian Institute of Technology Delhi, Hauz Khas, New Delhi- India.

[14] P. Srikhirin, S. Aphornratana and S. Chungpaibulpatana, "A review of absorption refrigeration technologies", Renewable and Sustainable Energy Reviews, vol. 5, (2001), pp. 343-372.

[15] V. Subramaniam and S. Garimella, "From measurements of hydrodynamics to computation of species transport in falling films", International Journal of Refrigeration, vol. 32, (2009), pp. 607-626.

[16] R. H. Wassenaar, "Measured and predicted effect of flowrate and tube spacing on horizontal tube absorber performance", International Journal of Refrigeration, vol. 19, (1996), pp. 347-355.

[17] G. Xie, G. Sheng, P. K. Bansal and G. Li, "Absorber performance of a water/lithium-bromide absorption chiller", Applied Thermal Engineering, vol. 28, (2008), pp. 1557-1562.

[18] Z. F. Xu, B. C. Khoo and N. E. Wijeysundera, "Mass transfer across the falling film: Simulations and experiments”, Chemical Engineering Science, vol. 63, (2008), pp. 2559-2575. 